Philosophy and Progress: Vols. LXI-LXII, January-June, July-December, 2017 ISSN 1607-2278 (Print), DOI: https://doi.org/10.3329/pp.v61i1-2.44201

\section{BEING, SUBSTANCE AND FORM IN ARISTOTLE'S METAPHYSICS}

\section{Md. Abdul Muhit}

The concepts of 'being', 'substance' and 'form' are central to Aristotle's metaphysics. According to him, there are different modes of being, and of all these different modes of being, substance is the primary mode of being, and First Philosophy is especially concerned with the mode of being which belongs to substances. Again, he tries to give an analysis of what a substance is in terms of the concept of form, and claims that it is essence or form that may be called substance in the truest and fullest sense. Thus we see that the concepts of 'being', 'substance' and 'form' are intimately related. This paper is an attempt to analyze clearly what Aristotle means by these three important concepts.

In the first chapter of Book IV of his Metaphysics Aristotle holds that there is "a science that studies being in so far as it is being" (1003a21). He calls this science "First Philosophy" or "Metaphysics" which is distinguished from other special sciences that do not treat being as being generally. Thus, physics studies natural objects - things that are subject to change. These are things that come into being and go out of

\footnotetext{
${ }^{*}$ Professor, Department of Philosophy, University of Dhaka E-mail: mamuhit@hotmail.com
}

being. So, physics studies certain beings (the natural ones), and it studies them in so far as they are subject to change. Metaphysics or the First Philosophy, on the other hand, studies beings in general (not just changeable ones) and it studies them "qua being" - in so far as they are beings.

Aristotle speaks of at least four senses of 'being'. The two most complete texts about the senses of being in Aristotle's Metaphysics would appear to be Book V (Chapter 7) and the Book VI (Chapter 2). In Book V we read the following:

'Being' means, first, accidental being, second, absolute being $[\ldots]$ The senses of essential being are those which are indicated by the figures of predication; for being has as many senses as there are ways of predication [...] Again 'to be' and 'is' mean that a thing is true, and 'not to be' that it is false. Similarly in affirmation and negation [...] Again, 'to be' means that some of these statements can be made in virtue of a potentiality and others in virtue of an actuality. $\left(1017^{\mathrm{a}} 7-1017^{\mathrm{b}} 2\right)$

In Book VI he reiterates these distinctions in another way:

But since the simple term 'being' is used in various senses, of which we saw that one was accidental, and another true (not-being being used in the sense of 'false'); and since besides these are the categories, e.g. the 'what', quality, quantity, place, time and any other similar meanings; and further besides all these the potential and actual [...] $\left(1026^{\mathrm{a}} 33-1026^{\mathrm{b}} 2\right)$

Based on the above quotations we may distinguish the following four senses of the expression 'is' or 'being', according to Aristotle.

a. Essential beings, or beings as distributed in the categories: For Aristotle, essential beings are those that are the figures of predication. In the Metaphysics he says: "Since, then, 
some predicates indicate what the subject is, others its quality, others quantity, others relation, others activity or passivity, others its 'where', others its 'when', 'being' has a meaning answering to each of these." (V, 6, 1017 25-28)

b. Potential and actual being: The 'being' or 'is' can refer to a capacity or to its present actualization. For example, 'is sentient' would naturally refer to the animal's capacity for sensation, and 'is a scholar' to a capacity acquired by training. But the former could be used to describe actual seeing or hearing, and the latter to describe a present exhibition of scholarship.

c. Accidental being: The accidental is what occurs, but not always nor of necessity, nor for the most part. For example, if the builder produces health it is accidental, because it is the nature not of a builder but of a doctor to do this. In this case, the builder happens to be a doctor.

d. Being as truth: The 'being' or 'is' can mean that a statement is true, and 'not-being' that it is not true but false. "... and this alike in affirmation and negation; e.g. 'Socrates is musical' means that this is true, or 'Socrates is not-white' means that this is true; but 'the diagonal of the square is not commensurate with the side' means that it is false to say it is." (Metaphysics, V, 6, 1017 $30-1017^{\mathrm{a}} 35$ )

The last two of the above-mentioned senses of being are excluded by Aristotle from his philosophical inquiry for the following reasons. According to Aristotle, accidental being is the object of no science, "... regarding the accidental, that there can be no scientific treatment of it." (Metaphysics, VI, 2, $1026^{\mathrm{b}} 4-5$ ) Because all science is of that which is always or for the most part, but the accidental is neither always nor for the most part. Aristotle holds that "the accidental is obviously akin to non-being" (Metaphysics, 1026 21), because it lacks the necessity and definiteness implied by being. When it comes to the sense of 'being as truth' Aristotle says that truth and falsity do not belong in things but in thought, and accordingly is not the principal type of being. Since being as truth is not in things but only in thought or in some affection of thought, the study of this kind of being must be excluded from metaphysics. As he puts it: "... that which is accidentally and that which is in the sense of being true must be dismissed. For the cause of the former is indeterminate, and that of the latter is some affection of the thought, and both are related to the remaining genus of being and do not indicate the existence of any separate class of being." (Metaphysics, VI, 4, $1027^{\mathrm{b}} 34-1028^{\mathrm{a}} 2$ )

After discarding these two senses of being which are not the object of metaphysics, Aristotle then pursues his analysis with respect to the others, especially the first. Indeed, even the second, i.e., being as capacity or actualization, is not quite independent. The distinction between these is one of the degrees within each of the modes distinguished under the first head. According to Aristotle, the science of being qua being is chiefly concerned with being in the various categories, and accordingly we will now focus on this sense of being.

In the Categories Aristotle has shown that 'being' is predicated of a number of things in various ways. Yet, he finds, 'being' is always expressed in reference to a certain definite nature. Thus, in Metaphysics, Aristotle remarks:

There are many senses in which a thing may be said to 'be', but they are related to one central point, one definite kind of thing, and are not homonymous. Everything which is healthy is related to health, one thing in the sense that it preserves health, another in the sense that it produces it, another in the sense that it is a symptom of health, another because it is capable of it. ... So, too, there are many senses in which a thing is said to be, but all refer to one starting-point; some 
things are said to be because they are substances, others because they are affections of substance, others because they are a process towards substance, or destructions or privations or qualities of substance, or productive or generative of substance, or of things which are relative to substance, or negations of some of these things or of substance itself. $\left(1003^{\mathrm{a}} 33-1003^{\mathrm{b}} 10\right)$

According to Aristotle, of all these different modes of being, substance is the primary modes of being. First philosophy is concerned with the general character of all these modes of being, but it is especially concerned with the modes of being which belongs to substances.

By substance, in the primary sense, Aristotle means that which is not predicable of a subject but of which everything else is predicated, or as he states the matter more clearly in the Categories: "that which is neither predicable of a subject nor present in a subject; for instance, the individual man or horse." $\left(2^{\mathrm{a}} 12-13\right)$ For Aristotle, substance is prior to the other categories in every sense: (i) in definition, for in the definition of each term the definition of its substance must be present; (ii) in order of knowledge, because we know each thing most fully, when we know what it is; (iii) in time, for of the other categories none can exist independently but only substance. Substances are the primary things that are; other types of being depend upon substantial being.

Now the question is: what is substantial being? In other words, what is the substantial element in individual thing? According to Aristotle, there are four main claimants to the title of 'substance', i.e., the substantial element in individual thing - essence, the universal, genus, and substratum. He holds that the substance of things cannot be their substratum or matter. Since substances are the subjects of attributes, and qualities etc. exist only in them, it might seem that one gets to substance finally only when all characteristics are stripped away - i.e. when one gets, not just from pale tall man to man but from man to absolutely indeterminate and characterless matter. But in fact this matter lacks the capacity for separate existence, or the individuality, the 'thisness', which are held to be the primary characteristics of substance.

Aristotle also rejects the claim of the universal to be called substance of anything. Because (i) the substance of anything is the substance peculiar to it, but the universal is common. It cannot therefore be the substance either of all its particulars or of any of them, since it is not peculiar to any; (ii) substance is what is not predicated of a subject, but the universal is predicated of some subject always. Aristotle argues that "it is plain that no universal attribute is a substance, and this is plain also from the fact that no common predicate indicates a 'this', but rather a 'such'." (Metaphysics, 1038 ${ }^{\mathrm{b}} 35-37$ )

Thus, for Aristotle, the substance of things is neither their substratum, nor their universal, nor their genus, which is a form of universal. Substance, he finally decides, is just the form and essence of a thing. For him, the essence is just what a particular thing $i s$. It is the inner nature, what makes a thing what it is, and is unfolded in definition. "The essence of each thing is what is said to be propter se". $\left(1029^{\mathrm{b}} 14\right)$ Therefore, accidental attributes are excluded from essence. Your essence is not to be musical; you were you before you were musical, and you may cease to be musical and still be you. Nor is the essence of surface white surface. "But not the whole of this is the essence of a thing; not that which something is in virtue of itself in the way in which a surface is white, because being a surface is not being white." (1029 $\left.9^{\mathrm{b}} 17-19\right)$ A definition, which is the statement of the essence of a thing, must not name the thing itself. 
Next, Aristotle denies that a term which is a complex of a substance plus something in another category, e.g., 'white man' is an essence. For, an essence is just what an individual thing is, and 'white man' is not just what an individual thing is. As he puts it: "For the essence is precisely what something $i s$; but when an attribute is asserted of a subject other than itself, the complex is not precisely what some 'this' is, e.g., white man is not precisely what some this $i s$, since thisness belongs only to substances. Therefore, there is an essence only of those things whose formula is a definition." (Metaphysics, 1030 2-6)

In Metaphysics (Book 7 Chapter 4) Aristotle finally affirms that it is essence or form ${ }^{*}$ which primarily belongs to substance. "And so now also since it is evident what language we use, essence will belong, just as the 'what' does, primarily and in the simple sense to substance, and in a secondary way to the other categories also, - not essence simply, but the essence of a quality or of a quantity." (1030 $29-31)$ In another passage, he says that "this is evident, that definition and essence in the primary and simple sense belong to substances." $\left(1030^{\mathrm{b}} 5-6\right)$ Aristotle's general position is that it is individuals in real

\footnotetext{
Form and essence are used interchangeably by Aristotle. In the Metaphysics he announces that: "By form I mean the essence of each thing and its primary substance" $\left(1032^{\mathrm{b}} 1-2\right)$, and "By form I mean essence" $\left(1035^{\mathrm{b}} 34-5\right)$. He uses form and essence interchangeably in his theory of substance. However, he never offers any explicit justification for this use. The identity is not self-evident. Whereas form is contrasted with matter, essence is contrasted with an accidental composite. It is surprising that, despite the overwhelming discussion of form or essence in the secondary literature, little attention has been paid to how form and essence can be used interchangeably. Most commentators (including this author) simply follow Aristotle and take this identity for granted without further argument.
}

species that are basic substances, and it is their essence or form that gives them this substantial being.

In a particularly difficult discussion in Book 7 chapter 6 of his Metaphysics Aristotle asks whether the essence of the individual and the individual itself are one and the same thing. His answer to this problem is that in some cases the individual is identical with its essence, in others not identical. If we talk of an entity that can be separated from an individual, even though only in thought, the essence and that entity are one and the same; if it cannot, then the essence is not identical with the individual. His most striking illustration of this point is to compare man with psyche (soul): psyche and the essence of psyche are the same, but man and the essence of man (which is his psyche) are not. "For 'soul' and 'to be soul' are the same, but 'to be man' and 'man' are not the same, unless even the bare soul is to be called man; and thus on one interpretation the thing is the same as its essence, and on another it is not." $\left(1043^{\mathrm{b}} 1-4\right)$ "...the soul of each individual is the individual itself." (1036 17$)$

Having decided that it is essence or form that may be called substance in the truest and fullest sense, Aristotle endeavours, in Metaphysics Book 7 chapter 17, to make his meaning clearer and more precise. The mode of approach is as follows: For him, substance is an originative source and cause, i.e. that it is what make things what they are. It is the answer to the question why? Now the question 'why?' is never of the form 'why is A A?' The sensible question that may be asked is: 'why is A B?', i.e. 'why does it thunder?' or 'why do these bricks and stones make a house?' In all such cases, we are looking for a cause which is - to speak abstractly - the essence, but in some cases, as in that of a house, the end to be subserved, and in some, as in that of thunder, the moving cause. If we ask, what makes the matter into a particular thing? 
The answer is, the presence of the essence of the particular thing, which is not another element in the thing alongside of its material elements nor anything compounded out of elements. Aristotle remarks:

And why is this individual thing, or this body having this form, a man? Therefore what we seek is the cause, i.e. the form, by reason of which the matter is some definite thing; and this is the substance of the thing. (1041 $\left.{ }^{\mathrm{b}} 5-8\right)$

Now, in naming essence or form as the answer to the question 'what is the cause of a thing's being, and therefore its substance?' Aristotle indicates that this answer is but an abstract one. If we ask what makes this flesh and bones into a man, or this bricks and stones into a house, it is no doubt a correct answer to say, the presence of the essence of man or the essence of a house. But this answer is scarcely informative. Aristotle himself points the way to a more real explanation by saying that what we describe abstractly as the essence is, viewed concretely, sometimes a final, sometimes an efficient cause. Normally, it is a final cause. The reason why this flesh and these bones make a man is that they are informed by the form of man, the human soul. But properly explicated, the reason is that it is so organized as to be able to perform the proper and peculiar function of man, i.e. is capable to rational and moral activity. The same is true of an artefact. What makes these bricks and stones into a house? The answer is, the fact that they are so arranged as to serve as a shelter for living things and goods. Aristotle remarks:

And so, in defining, those who define a house as stones, bricks, and timbers, are speaking of the potential house, for these are the matter; but those who define it as a covering for bodies and chattels, or add some other similar differentia, speak of the actuality; and those who combine both of these speak of the third kind of substance, which is composed of matter and form. $\left(1043^{\mathrm{a}} 14-19\right)$
Aristotle's main point is that the essence or form is not be thought of either as a component existing alongside of the material components, or as itself consisting of material components. If we view it in the former way we shall require a further principle of structure to explain how it is united with the material components. If we view it in the latter way we shall want to know how the material components are united to form the essence, i.e. we shall have to ask about the essence the same question that we asked originally about the concrete thing - what makes it what it is? We must pass clean way from any materialistic understanding of the essence and treat it as the structure of the concrete things.

Thus, for Aristotle, the substance of a thing is the principle of structure, the presence of which in a collection of materials makes them not a mere collection but an organized whole. And this principle of structure, the substantial element in individual things, is the form or the essence.

\section{References}

1. Ackrill, J.L. (2003), Aristotle the Philosopher, Oxford: Oxford University Press.

2. Allan, D.J. (1970), Philosophy of Aristotle, $2^{\text {nd }}$ ed., New York: Oxford University Press.

3. Copleston, Frederick. (1993), A History of Philosophy, vol. I: Greece and Rome, Image ed., New York: Doubleday.

4. Edel, Abraham. (1982), Aristotle and His Philosophy, Chapel Hill: University of North Carolina Press.

5. McKeon, Richard. (Edited with an introduction), (1941). The Basic Works of Aristotle, New York: Random House.

6. Ross, Sir David. (1995), Aristotle, $6^{\text {th }}$ ed., London: Routledge.

7. Taylor, A.E. (2012), Aristotle, New York: Dover Publications. 